\title{
Hubungan antara kadar kolesterol total dengan tekanan darah pada remaja obes
}

\author{
${ }^{1}$ Jason G. Rupang \\ ${ }^{2}$ Sarah M. Warouw \\ ${ }^{2}$ Nurhayati Masloman
}

\author{
${ }^{1}$ Kandidat Skripsi Fakultas Kedokteran Universitas Sam Ratulangi Manado \\ ${ }^{2}$ Bagian Ilmu Kesehatan Anak Fakultas Kedokteran Universitas Sam Ratulangi Manado \\ Email: jasongilb22@gmail.com
}

\begin{abstract}
Obesity is a disorder or disease that characterized by excessive accumulation of adipose tissue. Obesity is a world health problem and increasingly common in various countries. The most common causes of obesity are genetic factors, physical inactivity, and unhealthy diet. Obesity and high total cholesterol level in adolescent cause various chronic diseases, such as diabetes mellitus, coronary heart disease, and cerebrovascular disease. The aim of this study is to investigate the correlation between total cholesterol level and blood pressure in obese adolescents. This is an analytical observational study, using cross sectional design. Samples were chose using consecutive sampling technique in two junior high schools and senior high schools in Tomohon Tengah district, Tomohon City. Samples are adolescent age 13-15 years old, which was selected through anthropometric examination, blood pressure measurement, and blood sample collection. The result from 38 samples showed that there is no correlation between total cholesterol level with blood pressure, both systolic blood pressure $(p=0.867)$ and diastolic blood pressure $(p=0.627)$. Conclusion: There is no correlation between total blood cholesterol and blood pressure (both systolic and diastolic). Parents should pay more attention to the children's health and diet to prevent a prolonged obesity.
\end{abstract}

Keywords: obesity, total cholesterol, blood pressure, adolescent

\begin{abstract}
Abstrak: Obesitas atau kegemukan adalah suatu kelaianan atau penyakit yang di tandai oleh penimbunan jaringan lemak dalam tubuh secara berlebihan. Obesitas merupakan masalah kesehatan dunia yang semakin sering ditemukan di berbagai Negara. Penyebab paling sering menyebabkan obesitas adalah faktor genetik, kurangnya aktifitas fisik dan pola makan yang tidak sehat. Obesitas dan kolesterol total yang berlebih pada remaja merupakan penyebab terjadinya berbagai penyakit kronik termasuk hipertensi, diabetes melitus, penyakit jantung koroner, dan penyakit serebrovaskular. Penelitian ini bertujuan untuk mengetahui hubungan antara kadar kolesterol total dengan tekanan darah pada remaja obes. Jenis penelitian ialah analitik observasional dengan rancangan potong lintang dengan teknik consecutive sampling pada dua SMP dan dua SMA di Kecamatan Tomohon Tengah, Kota Tomohon pada bulan September hingga November 2016. Sampel pada penelitian adalah remaja yang berusia 1315 tahun. Data yang diambil melalui pemeriksaan antropometri, pemeriksaan tekanan darah, dan pengambilan sampel darah. Hasil penelitian dari masing - masing 38 sampel menunjukkan tidak terdapat hubungan antara kadar kolesterol total dengan tekanan darah sistolik ( $p=0.867)$ dan tekanan darah diastolik $(p=0.627)$.

Simpulan: Tidak terdapat hubungan antara kadar kolesterol total dengan tekanan darah (TDS\&TDD). Orang tua diharapkan lebih memperhatikan kesehatan dan pola makan untuk mencegah terjadinya obesitas yang berkepanjangan.
\end{abstract}

Kata kunci: obesitas, kolesterol total, tds, tdd, remaja 
Obesitas atau kegemukan adalah suatu kelainan atau penyakit yang ditandai oleh penimbunan jaringan lemak dalam tubuh secara berlebihan. Obesitas dapat terjadi pada semua golongan umur, akan tetapi pada anak biasanya di dapatkan pada usia menjelang remaja dan dalam masa remaja. ${ }^{1}$ Prevalensi overweight dan obes meningkat pada anak di dunia meningkat dari 4,2\% di tahun 1990 menjadi $6,7 \%$ di tahun 2010, dan diperkirakan akan mencapai $9,1 \%$ di tahun $2020 .^{2}$

Data dari hasil Riset Kesehatan Dasar (Riskesdas) 2013 di dapatkan prevalensi obesitas pada anak balita pada tahun 2007, 2010, dan 2013 berdasarkan berat badan (BB) menurut tinggi badan (TB) lebih dari Zscore 2 menggunakan baku antropometri anak balita WHO 2005 berturut-turut $12,2 \%, 14,0 \%$ dan $11,9 \%$, serta pada anak berusia 5-12, 13-15, dan 16-18 tahun berturut - turut $8,8 \%, 2,5 \%$, dan $1,6 \%$ berdasarkan indeks massa tubuh menurut umur lebih dari Zscore 2 menggunakan baku antropometri WHO 2007 untuk anak berumur 5-18 tahun. ${ }^{3}$

Peningkatan IMT merupakan faktor resiko utama terjadinya gangguan atau penyakit seperti: Penyakit kardiovaskuler (seperti penyakit jantung dan stroke), Gangguan muskuloskeletal (terutama osteoatritis - penyakit degeneratif yang menyerang sendi); Dislipidemia, Diabetes, Beberapa kanker (endometrium, payudara, dan kolon). Resiko dari penyakit-penyakit diatas meningkat seiring dengan meningkatnya IMT (Indeks Masa Tubuh). ${ }^{4}$

Kolesterol adalah sterol yang paling dikenal oleh masyarakat. Kolesterol merupakan bahan antara pembentukan sejumlah steroid penting, seperti asam empedeu, asam folat, hormone-hormon korteks adrenal, estrogen, androgen, dan progesterone. Sebaliknya kolesterol dapat membahayakan tubuh. Kolesterol bila terdapat dalam jumlah terlalu banyak di dalam darah dapat membentuk endapan pada dinding pembuluh darah sehingga menyebabkan penyempitan yang dinamakan aterosklerosis. Bila penyempitan terjadi pada pembuluh darah jantung dapat menyebabkan penyakit jantung coroner dan pembuluh darah otak penyakit serebrovaskular. Kolesterol di dalam tubuh terutama diperoleh dari hasil sintesis di dalam hati. Bahan bakunya diperoleh dari kerbohidrat, protein, atau lemak. Jumlah yang disintesis bergantung pada kebutuhan dan jumlah yang diperoleh dari makanan. ${ }^{5}$

Peningkatan kegemukan dan obesitas pada anak di seluruh dunia ikut mendongkrak prevalesi hipertensi pada anak, terutama hipertensi primer. Obesitas diketahui merupakan salah satu faktor yang meningkatkan resiko hipertensi primer pada anak. Selain itu juga peningkatan kadar kolesterol pada anak obes berpengaruh terhadap peningkatan tekanan darah. Dalam sebuah penelitian oleh Davis dkk, tentang hubungan kolesterol dengan peningkatan tekanan darah didapatkan hasil hasil yang bermakna. ${ }^{6}$

Berdasarkan uraian di atas, peneliti tertarik untuk mengetahui hubungan antara kadar kolesterol total dengan tekanan darah pada remaja obes.

\section{METODE PENELITIAN}

Penelitian observasional analitik dengan rancangan potong lintang dan menggunakan metode consecutive sampling. Penelitian dilakukan di dua SMP dan dua SMA di Kecamatan Tomohon Tengah, Kota Tomohon pada bulan September hingga November 2016. Sampel pada penelitian adalah remaja usia 13-15 tahun.

Kriteria inklusi ialah murid laki-laki dan perempuan yang tercatat dalam register sekolah dengan umur 13 - 15 tahun. Telah mendapat persetujuan dari orang tua murid untuk mengikuti penelitian. Murid yang tergolong dalam kriteria obesitas. Kriteria eksklusi ialah murid yang sakit atau murid yang dalam masa pengobatan yang dapat memengaruhi kadar kolesterol dan tekanan darah. Subjek yang memenuhi kriteria inklusi dilakukan pengambilan data melalui pengukuran antropometri, pengukuran tekanan darah sistolok dan diastolik (TDS dan TDD), dan pengambilan darah sebanyak $3 \mathrm{cc}$. 


\section{HASIL PENELITIAN}

Penelitian ini dilakukan pada dua sekolah menegah pertama dan dua sekolah menegah atas di Kecamatan Tomohon Tengah, Kota Tomohon. Total jumlah sampel yang diteliti adalah 38 anak yang memenuhi kriteria obesitas.

Tabel 1. Distribusi Frekuensi Responden Obes Berdasarkan Jenis Kelamin

\begin{tabular}{ccc}
\hline Jenis kelamin & n & \% \\
\hline Laki-laki & 19 & 50 \\
Perempuan & 19 & 50 \\
Total & 38 & 100 \\
\hline
\end{tabular}

Tabel 2. Distribusi Frekuensi Responden Obes Berdasarkan Umur

\begin{tabular}{ccc}
\hline Umur & $\mathbf{n}$ & $\mathbf{\%}$ \\
\hline 13 Tahun & 15 & 39.5 \\
14 Tahun & 15 & 39.5 \\
15 Tahun & 8 & 21.1 \\
Total & 38 & 100.0 \\
\hline
\end{tabular}

Tabel 3. Distribusi Frekuensi Responden Laki laki Obes Berdasarkan Tekanan Darah Sistolik

\begin{tabular}{ccc}
\hline $\begin{array}{c}\text { Tekanan Darah } \\
\text { Sistolik }\end{array}$ & n & \% \\
\hline Normal & 10 & 52.6 \\
Hipertensi tingkat 1 & 4 & 21.1 \\
Hipertensi tingkat 2 & 5 & 26.3 \\
Total & 19 & 100.0 \\
\hline
\end{tabular}

Tabel 4. Distribusi Frekuensi Responden Perempuan Obes Berdasarkan Tekanan Darah Sistolik

\begin{tabular}{ccc}
\hline $\begin{array}{c}\text { Tekanan Darah } \\
\text { Sistolik }\end{array}$ & n & \% \\
\hline Normal & 10 & 52.6 \\
Hipertensi tingkat 1 & 7 & 36.8 \\
Hipertensi tingkat 2 & 2 & 10.5 \\
Total & 19 & 100.0 \\
\hline
\end{tabular}

Tabel 5. Distribusi Frekuensi Responden Laki laki Obes Berdasarkan Tekanan Darah Diastolik

\begin{tabular}{ccc}
\hline $\begin{array}{c}\text { Tekanan Darah } \\
\text { Diastolik }\end{array}$ & n & \% \\
\hline Normal & 15 & 78.9 \\
Hipertensi tingkat 1 & 4 & 21.1 \\
Hipertensi tingkat 2 & 0 & 0 \\
Total & 19 & 100.0 \\
\hline
\end{tabular}

Tabel 6. Distribusi Frekuensi Responden Perempuan Obes Berdasarkan Tekanan Darah Diastolik

\begin{tabular}{ccc}
\hline $\begin{array}{c}\text { Tekanan Darah } \\
\text { Diastolik }\end{array}$ & n & \% \\
\hline Normal & 16 & 84.2 \\
Hipertensi tingkat 1 & 3 & 15.8 \\
Hipertensi tingkat 2 & 0 & 0 \\
Total & 19 & 100.0 \\
\hline
\end{tabular}

Tabel 7. Nilai Minimun, Maximum, Mean dan Std. Deviasi

\begin{tabular}{lcccc}
\hline & Min & Max & Mean & SD \\
\hline KT & 122 & 258 & 173.95 & 32.201 \\
TDS & 100 & 170 & 123.95 & 15.861 \\
TDD & 60 & 90 & 78.42 & 7.893 \\
\hline
\end{tabular}

Tabel 8. Hasil Tabulasi Silang Kadar Kolesterol Total Berdasarkan TD Sistolik Pada Responden Laki-laki Obes

\begin{tabular}{cccccccc}
\hline & & \multicolumn{3}{c}{ TD Sistolik } & \multicolumn{2}{c}{} \\
\cline { 2 - 6 } & & \multicolumn{2}{c}{$\mathrm{N}$} & \multicolumn{2}{c}{ TN } & \multicolumn{2}{c}{ Total } \\
\cline { 2 - 7 } & $\mathrm{n}$ & $\%$ & $\mathrm{n}$ & $\%$ & $\mathrm{n}$ & $\%$ \\
\hline \multirow{2}{*}{ KT } & $\mathrm{N}$ & 9 & 47 & 7 & 37 & 16 & 84 \\
& TN & 1 & 5 & 2 & 11 & 3 & 16 \\
\multicolumn{2}{c}{ Total } & 10 & 52 & 9 & 48 & 19 & 100 \\
\hline
\end{tabular}

Tabel 9. Hasil Tabulasi Silang Kadar Kolesterol Total Berdasarkan TD Sistolik Pada Responden Perempuan Obes

\begin{tabular}{|c|c|c|c|c|c|c|c|}
\hline & \multicolumn{4}{|c|}{ TD Sistolik } & \multirow{2}{*}{\multicolumn{2}{|c|}{ Total }} \\
\hline & & \multicolumn{2}{|c|}{$\mathrm{N}$} & \multicolumn{2}{|c|}{$\mathrm{TN}$} & & \\
\hline & & $\mathrm{n}$ & $\%$ & $\mathrm{n}$ & $\%$ & $\mathrm{n}$ & $\%$ \\
\hline \multirow{2}{*}{ KT } & $\mathrm{N}$ & 7 & 37 & 7 & 37 & 14 & 74 \\
\hline & $\mathrm{TN}$ & 3 & 16 & 2 & 10 & 5 & 26 \\
\hline \multicolumn{2}{|c|}{ Total } & 10 & 53 & 9 & 47 & 19 & 100 \\
\hline
\end{tabular}

Tabel 10. Hasil Tabulasi Silang Kadar Kolesterol Total Berdasarkan TD Diastolik Pada Responden Laki-laki Obes

\begin{tabular}{cccccccc}
\hline & \multicolumn{4}{c}{ TD Diastolik } & \multicolumn{2}{c}{} \\
\cline { 2 - 6 } & \multicolumn{2}{c}{$\mathrm{N}$} & \multicolumn{2}{c}{ TN } & \multicolumn{2}{c}{ Total } \\
\cline { 2 - 7 } & $\mathrm{n}$ & $\%$ & $\mathrm{n}$ & $\%$ & $\mathrm{n}$ & $\%$ \\
\hline \multirow{2}{*}{ KT } & $\mathrm{N}$ & 13 & 68 & 3 & 16 & 16 & 84 \\
\multicolumn{2}{c}{ Total } & 15 & 71 & 1 & 5 & 3 & 16 \\
& TN & 2 & 4 & 21 & 19 & 100 \\
\hline
\end{tabular}

Berdasarkan hasil uji Chi-Square diperoleh nilai 0.028 dan nilai signifikan sebesar 0.867. Karena nilai signifikan $0.867>0.05$ maka tidak terdapat hubungan 
antara kolesterol total dengan tekanan darah sistolik (Tabel 12).

Tabel 11. Hasil Tabulasi Silang Kadar Kolesterol Total Berdasarkan TD Diastolik Pada Responden Perempuan Obes

\begin{tabular}{cccccccc}
\hline & \multicolumn{4}{c}{ TD Diastolik } & \multirow{2}{*}{ Total } \\
\cline { 2 - 6 } & \multicolumn{2}{c}{$\mathrm{N}$} & \multicolumn{2}{c}{ TN } & \multicolumn{2}{c}{} \\
\cline { 2 - 6 } & $\mathrm{n}$ & $\%$ & $\mathrm{n}$ & $\%$ & $\mathrm{n}$ & $\%$ \\
\hline \multirow{2}{*}{ KT } & $\mathrm{N}$ & 11 & 58 & 3 & 16 & 14 & 74 \\
& TN & 5 & 26 & 0 & 0 & 5 & 26 \\
\multicolumn{2}{c}{ Total } & 16 & 84 & 3 & 16 & 19 & 100 \\
\hline
\end{tabular}

Tabel 12. Hubungan Kadar Kolesterol Total dengan Tekanan Darah Sistolik

\begin{tabular}{ccc}
\hline Variabel & $\mathbf{x}^{2}$ & $\mathbf{P}$ \\
\hline KT - TDS & 0.028 & 0.867 \\
\hline
\end{tabular}

Berdasarkan hasil uji Chi-Square diperoleh nilai 0.236 dan nilai signifikan sebesar 0.627. karena nilai signifikan 0.627 $>0.05$ maka tidak terdapat hubungan antara kolesterol total dengan tekanan darah diastolik (Tabel 13).

Tabel 13. Hubungan Kadar Kolesterol Total dengan Tekanan Darah Diastolik

\begin{tabular}{ccc}
\hline Variabel & $\mathbf{x}^{2}$ & $\mathbf{P}$ \\
\hline KT -TDD & 0,236 & 0,627 \\
\hline
\end{tabular}

\section{BAHASAN}

Penelititan ini dilakukan sejak bulan September 2016 sampai bulan November dan untuk pengambilan data dilakukan sejak bulan oktober 2016 dan yang menjadi sampel adalah siswa dan siswi sekolah menegah pertama dan siswa siswi sekolah menegah atas yang bersekolah di satu SMP swasta, satu SMP negeri, satu SMA swasta dan satu SMK negeri di Kecamatan Tomohon Tengah, Kota Tomohon dengan umur 13 - 15 tahun. Sampel yang diambil menggunakan metode consecutive sampling yaitu pengambilan sampel hingga memenuhi total jumlah sampel yang dibutuhkan dan sesuai dengan kriteria inklusi. Dari hasil uji Chi-Square pada hubungan antara kadar kolesterol total dengan tekanan darah sistolik diperoleh nilai $\mathrm{x}^{2}=0.028$ dan nilai $\mathrm{p}=0.867$. Dari hasil tersebut dinyatakan bahwa tidak terdapat hubungan antara kadar kolesterol total dengan tekanan darah sistolik maka $\mathrm{H}_{0}=$ diterima $(\mathrm{p}=0.867>0.05)$. Kemudian dari hasil uji Chi-Square pada hubungan antara kadar kolesterol total dengan tekanan darah diastolik diperoleh nilai $\mathrm{x}^{2}=$ 0,236 dan nilai $\mathrm{p}=0,627$. Dari hasil tersebut dinyatakan bahwa tidak terdapat hubungan antara kadar kolesterol total dengan tekanan darah diastolik maka $\mathrm{H}_{0}=$ diterima ( $\mathrm{p}=0,627>0.05)$.

Hal ini sejalan dengan penelitian yang dilakukan oleh Hariyanto dkk, dimana mereka memiliki hasil yang sama dimana tidak ada hubungan antara kadar kolesterol total dengan tekanan darah sistolik, demikian juga dengan tekanan darah diastolik. pada 38 anak obesitas. Namun berbeda dengan penelitian Davis dkk, dengan jumlah yang lebih besar mendapatkan hubungan yang bermakna. Berbagai faktor dapat mempengaruhi hasil penelitian tersebut seperti faktor lingkungan, budaya, status gizi, jenis kelamin, jenis makanan yang dikonsumsi sehari-hari yang berbeda disetiap tempat, aktifitas fisik dari sampel yang diteliti serta usia sampel. ${ }^{35-38}$

Berdasarkan tabel 11 dan 12 kadar kolesterol total berdasarkan jenis kelamin ditemukan bahwa perempuan memiliki kadar kolesterol total kategori tinggi berjumlah 5 orang ( $13.1 \%$ ) sedangkan laki-laki yang memiliki kadar kolesterol total kategori tinggi lebih rendah yaitu berjumlah 3 orang $(7.9 \%)$

Keterbatasan penelitian ialah variabel kolesterol total tidak disertakan dengan pemeriksaan HDL dan LDL. Selain itu jumlah sampel hanya 38 anak dan tidak dibahas mengenai pola makanan yang dikonsumsi.

\section{SIMPULAN}

Dari hasil penelitian dan bahasan dapat disimpulkan bahwa tidak terdapat hubungan antara kadar kolesterol total dengan tekanan darah sistolik maupun tekanan darah diastolik pada remaja obes di 
Kecamatan Tomohon Tengah, Kota Tomohon.

\section{SARAN}

Disarankan untuk memberikan penyuluhan kepada masyarakat terutama kepada orang tua, perbanyak aktifitas fisik seperti berolahraga, mengonsumsi makanan yang sehat, mengurangi jenis makanan yang tinggi karbohidrat dan kolesterol, serta menghimbau orang tua agar lebih sering melakukan pemeriksaan tekanan darah agar dapat mencegah risiko penyakit akibat peningkatan tekanan darah.

\section{DAFTAR PUSTAKA}

1. Sjarif DR. Obesitas pada anak dan permasalahannya. In: Hot Topics in Pediatrics II. 2. Jakarta: 2002.p.219-31.

2. de Onis M, Blossner M, Borghi E. Global Prevalence and Trends of Overweight and Obesity Among Preschool Children. Am J Clin Nutr. 2010;92 : 1257-64

3. Maffeis C, Schutz Y, Grezzani A, Provera S, Piancentini G, Tato L. Meal- induced thermogenesis and obesity: is aa fat meal a risk factor for fat gain in children? J Clin Endocrinol Metab. 2001;86:214-9.

4. Almatsier S. Prinsip Dasar Ilmu Gizi. Jakarta. 2009. p. 63.

5. Davis PH, Dawson JD, Riley WA, Lauer RM. Carotid intimal-media thickness is related to cardiovascular risk factors measured from childhood trough middle age the Muscatine study. Circulation 2001;104:2815-9.

6. Hariyanto D, Madiyono B, Sjarif DR, Sudigdo Sastroasmoro. Hubungan Ketebalan Tunika Intima Media Arteri Carotis dengan Obesitas pada Remaja. Sari pediatri. 2009. P.159-65.

7. Adam JMF. Reducing cardiovascular risk the need for combination therapy. The $5^{\text {th }}$ National Obesity Symposium. Jakarta, May $20^{\text {th- }} 21^{\text {th }}, 2006$.

8. NCEP Expert Panel of Blood Cholesterol Levels in Children and Adolescents. National Cholesterol Education Program (NCEP): Highlights of the Report of the Expert Panel on Blood Cholesterol Levels inChilden and Adolesents. Pediatrics 1992;89:495-501 